\title{
Dynamic Pricing Can Help Companies for International Road Transportation Survive COVID-19 Pandemic Crisis
}

\author{
Maria Cvetanova Hristova - Politicova \\ Doctorate student, University of National and World Economy (UNWE) \\ Sofia, Bulgaria \\ Email: Lazur2000 [AT] yahoo.com
}

\begin{abstract}
The main goal of this article is to reveal the advantages of dynamic pricing implementation in the international transportation of cargo by road. It will be clarified what dynamic pricing is and under what conditions and in what business areas it is suitable to be applied. The fluctuation in demand of freight services will be observed as well as its impact on price and the revenues of transportation companies. Comparisons will be made of the company revenues in case it uses dynamic prices or sticks to static tariffs. Finally, conclusions will be reached for company efficiency according to its choice of pricing strategy.
\end{abstract}

Keywords---- dynamic pricing, price discrimination, static tariffs, revenues, consumer profile, pricing algorithms, fluctuations in demand, groupage shipment, price per ldm

\section{INTRODUCTION}

The period March - June 2020 when the Covid- 19 spread in Europe and anti-pandemic measures are taken by European authorities is very challenging for many businesses [13]. The essential role of freight transport and logistics was realized and a package of new rules were accepted in Europe [12]. Most effective among them are the introduction of green lanes at internal and external borders, establishing a framework for temporary extension of the validity of a number of freight, vehicle and personnel related certificates and control documents, introducing more flexibility in the driving and rest times for the drivers and lifting of traffic bans for heavy goods vehicles[14]. International truck transportation does not suffer a lock down but suffered from the lock downs of its major customers - the industrial companies. The market situation gets really turbulent - the demand of truck transportation services becomes extremely unstable - which results in great fluctuations in the prices. Implementation of effective pricing strategy is crucial for trucking to keep their revenues and cover at least their direct costs.

\section{METHODOLOGY}

The main methods involved in the study are the most popular scientific methods these of analysis, synthesis, induction and deduction [3]. Mathematical methods as calculation and extrapolation are also applied. Method of induction is applied in the empiric verification of hypothesis. There is also an attempt to model a formula for a dependable changeable by most adequate combination of certain determinants for a given case multiplied by a fixed basic value. Raw data are collected on the field(working place), systematized and analyzed as dynamic rows. The tendencies are displayed by graphs. Some secondary data are obtained from raw data by certain calculations or obtained from various sources as statistical organizations and periodicals. The process of analysis is supported by scientific descriptions and comparisons of data. Certain tendencies are observed and on their basis respective conclusions are drawn.

\section{ANALYSIS \&FINDINGS}

\subsection{Dynamic pricing and favoring conditions for application}

Dynamic pricing originates from price discriminations described by the English economist Arthur Sesyl Pygu in his work "The Economics of Welfare "(1920) [1]. The core of both is segmentation of consumers into different parts according to their ability and willingness to pay different prices for one and the same product [2]. In the dynamic pricing, however segmentation has evolved into personalization - the customer has its one consumer profile due to the development of information technologies. Again due the surge in digital sciences, special algorithms for price tailoring are applied. 
Another specific aspect for dynamic pricing to be emphasized is, that price change is a function of fluctuations in demand [8]. Customers might have their personal profile, but they can get different prices depending on the business activity at a precise moment [7].

Still one thing is common for price segmentation and dynamic pricing - the aim for better profits.

To apply dynamic pricing in trucking services we have to concentrate on following moments:

$\checkmark \quad$ To develop and keep customer profiles. Loyalty of customer, the regularity of orders, the volume of orders are key points in customer profile;

$\checkmark \quad$ To be conscious for seasonal changes in demand and other unexpected changes due to casual factors. Market situation is essential for effective dynamic pricing;

$\checkmark \quad$ To have a pricing algorithm is the tool to effect dynamic pricing;

\subsection{Model to obtain the dynamic price}

The first step in reaching to such a model is to define the most influential changeable for the formation of the dynamic price and weigh them to get coefficients:

$\mathrm{K}_{1}$ - number of request(indicates increased demand)

$\mathrm{K}_{2}$ - indicates irregular dimensions, weight of shipment

$\mathrm{K}_{3}$ - indicated extra requirements for loading unloading, exact hour for loading/delivery

$\mathrm{K}_{4}$ - indicates regularity of orders, customer loyalty

$\mathrm{K}_{5}$ - seasonal changes in demand

$\mathrm{K}_{6}$ - urgent deliveries

Using the am price determinants we can form the following model:

$P_{1}=P * k_{1} * k_{2} * k_{3} * k_{4} \ldots$

$\mathrm{P}_{1}$ - dynamic price

$\mathrm{P}$ - basic, initial price

The application of the model will be illustrated further in the study to show how it can improve revenues of trucking company.

Dynamic pricing is generally applied in businesses where demand is unstable with high peaks and steep declines [11]. Such are mostly services - airway services, railway services, tourist services, in restaurants, taxi services etc. [9]. Important feature of services is that they can not be stored. The moment of consumption is very closed to the moment of production i.e. the human resources and capacities such as places in a concert hall, in a plane saloon or restaurant, the fleet of taxis or trucks might be really strained or on the opposite free, empty [9]. The different prices in answer of different demand is obligatory and essential for survival and profitability of many companies. It is not always a question of bigger profits but of sheer survival as was for the trucking companies during the period of anti-pandemic measures aimed to stop the spread of Covid-19 virus. The trucking companies were driven to take loads at extremely low price - below costs - just to minimize losses. (This will be further explored in the study below)

\subsection{Transportation services during the period March - October 2020}

\subsubsection{Fluctuations in demand}

Covid-19 pandemic crisis has many aspects. It was very challenging period for the international truck transportation in financial aspect.

A basic postulate for economy is that transported volumes are a key indicator for the state of economic cycle. It is also well known that the changes in transportation show themselves with considerable lag [6]. The first anti-pandemic measures applied by the authorities of European countries provoke surge in the demand of truck transportation services between Bulgaria and other European countries. Industrial companies decide to finalize the initiated projects by importing materials or exporting production [13]. Trade companies decide to pile some stock of essential commodities as people grow crazy for buying foodstuff with longer validity period and other consumer goods. So the first wave starts when the first antipandemic measures are initiated for the first time in Europe. Even though at that time in Bulgaria still there are no measures, the higher demand of road transportation services is already a fact. Everybody is in a hurry to bring or send certain cargo because the unknown future is worst than the real hard one. 
The increased demand in trucking capacities leads to elevation of prices both of groupage shipments and full truck loads between Bulgaria and the other European countries by 10-25\% depending on the destination [6]. For less than a week the prices reach levels that have not been for last 13 years i.e. since year 2007 when Bulgaria wasn`t an EU member.

After the first wave of hectic transportation, following the anti-pandemic measures taken by more and more European countries the demand for transportation services begins to slow down. As many global companies in Germany, Netherlands and Belgium, Italy working for automotive and other key industries close it definitely leads to reduced volumes of cargo for transportation [14]. The lock-down of trade centers, restaurants and bars is the reason for the reduction of demand in consumer goods and the shrunk of import to Bulgaria in the period March - October. The table below reveals clearly the reduced activity in international trade compared to the respective period in $2019^{1}$.

Table: 1 Changes in the value of export and import of Bulgaria for the period January October 2020 compared to the same period of 2019( in \%)

\begin{tabular}{|c|c|c|c|c|c|c|}
\hline \multirow{2}{*}{ Months/Periods } & \multicolumn{3}{|c|}{ Exprt - FOB } & \multicolumn{3}{|c|}{ Import - CIF } \\
\hline & total & $\mathrm{EU}$ & $\begin{array}{l}\text { third } \\
\text { parties }\end{array}$ & total & EU & $\begin{array}{l}\text { Third } \\
\text { parties }\end{array}$ \\
\hline I & 6.3 & 4.8 & 9.0 & 4.3 & 5.7 & 2.4 \\
\hline II & 3.2 & 4.2 & 1.4 & -1.6 & 2.1 & -6.9 \\
\hline III & -6.3 & -8.9 & -1.3 & -6.4 & -8.3 & -2.8 \\
\hline I - III & 1.0 & -0.1 & 3.0 & -1.3 & -0.6 & -2.5 \\
\hline IV & -16.8 & -19.7 & -11.5 & -31.4 & -32.4 & -29.9 \\
\hline V & -19.8 & -17.8 & -23.4 & -28.1 & -28.6 & -27.3 \\
\hline VI & -5.6 & -0.8 & -14.0 & -6.3 & -7.3 & -4.5 \\
\hline IV - VI & -14.1 & -12.9 & -16.3 & -22.4 & -23.1 & -21.2 \\
\hline I - VI & -6.5 & -6.4 & -6.7 & -12.0 & -12.1 & -12.0 \\
\hline VII & -9.8 & -6.4 & -16.1 & -14.9 & -15.1 & -14.7 \\
\hline VIII & -14.5 & -8.6 & -24.6 & -10.0 & -10.6 & -9.2 \\
\hline IX & -1.5 & 2.4 & -8.1 & -1.3 & 2.3 & -6.4 \\
\hline VII - IX & -8.6 & -4.3 & -16.2 & -8.9 & -8.1 & -10.2 \\
\hline I - IX & -7.2 & -5.7 & -10.1 & -11.0 & -10.7 & -11.4 \\
\hline $\mathrm{X}$ & -10.8 & -5.0 & -20.9 & -10.3 & -12.4 & -6.9 \\
\hline $\mathrm{I}-\mathrm{X}$ & -7.6 & -5.6 & -11.3 & -10.9 & -10.9 & -10.9 \\
\hline
\end{tabular}

Source: https://www.nsi.bg/bg

\footnotetext{
${ }^{1}$ https://www.nsi.bg/bg
} 


\subsubsection{Changes in market prices of transportation services and revenues of trucking companies}

The reduced import/export operations lead to reduced value of transported by road volumes. As the market for trucking services in Bulgaria and Europe is very competitive one the prices are formed according to the basic economic law for supply and demand [15]. As a result decrease in prices follows of about 25-30\% which is more than was the increase observed in the beginning. The dynamics in price determinants - supply and demand is the main condition for dynamic pricing to be applied.

Table: 2 Transport prices in EUR per ldm of groupage shipments import Germany - Bulgaria for the period January - June 2020

\begin{tabular}{|c|r|r|r|r|r|r|}
\hline month/ $/$ price & Jan & Feb & March & April & May & June \\
\cline { 2 - 7 } & 178 & 184 & 194 & 138 & 143 & 154 \\
\hline
\end{tabular}

Source: Real company data

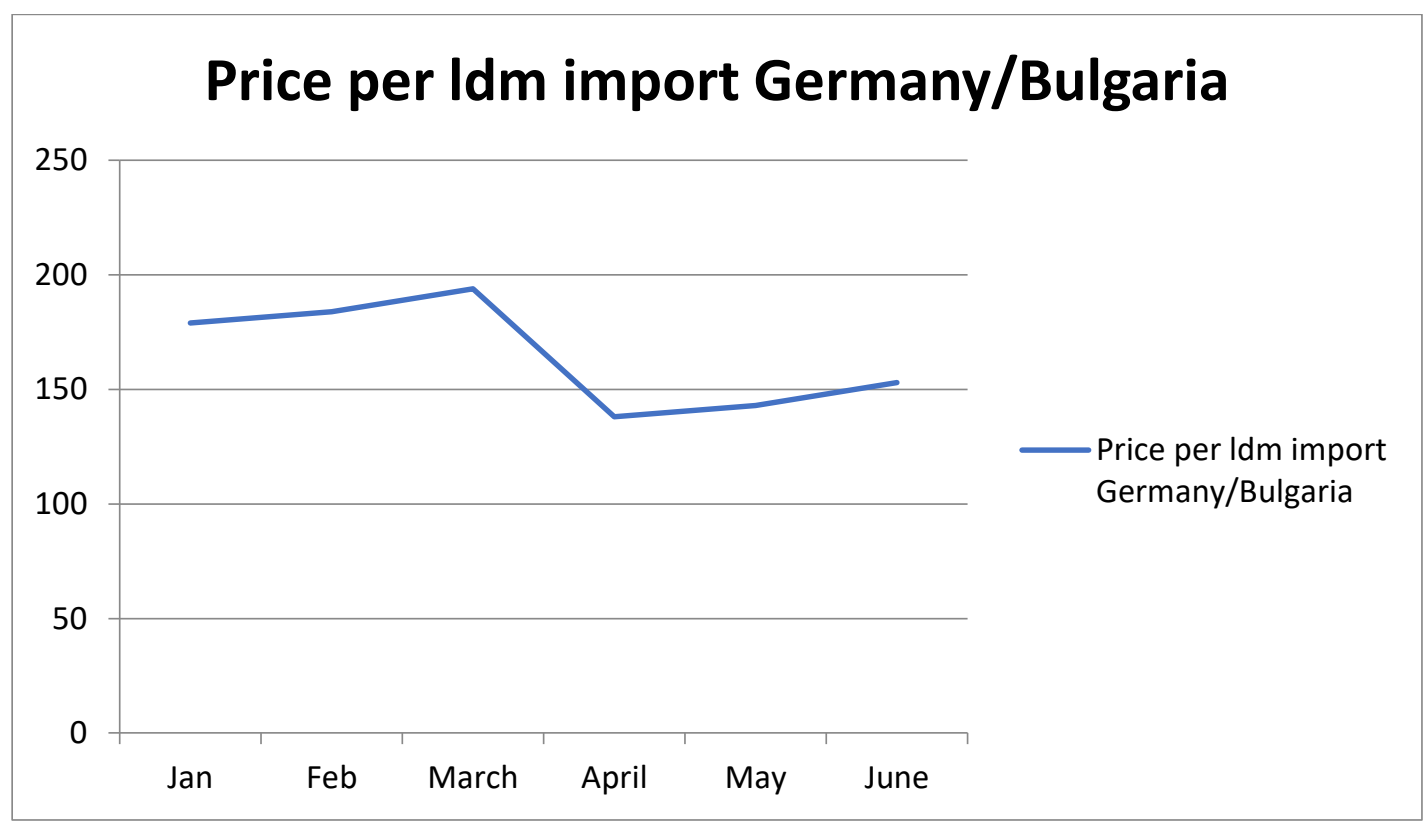

Figure: 1 Price per ldm import Germany/ Bulgaria

Source: Company date, calculations by the author

Undoubtedly the unpredictable and abrupt decrease in trucking prices leads to worse revenues for the companies.

The financial results of the global company Kuehne + Nagel for the first half of 2020 are worse than the ones for the same period of 2019. The gross revenues of the company are 9808 million CHF which is by $7.5 \%$ less that the same period 2019 [16]. The gross profit of the company decreases by $9.1 \%$ down to 3650 million CHF. The net profit for the first three months of 2020 drops by $23.2 \%$ in comparison to the levels of $2019^{2}$.

\subsection{Comparison of revenues from business activities by applying dynamic pricing or sticking to static} tariffs

The dynamic pricing can be applied by two ways:

- $\quad$ using the model shown in 4.2.

Here is the following example case:

Trucking company A gets request by e new customer B for transportation from Italy to Bulgaria in the end of July a period of high demand when most Italian shippers are about to close for the summer holidays. The shipment is a bundle

${ }^{2}$ Kuehne+Nagel AG, Annual report 2020 
of $6 \mathrm{~m}$ long steel rods with total $d=0.4 \mathrm{~m}$. The trucking company has two options - to use the static tariff or to form a dynamic price:

1/In the first option the shipment with irregular dimensions just should be equaled to the respective ldm $6 \mathrm{~m} / 6=1 \mathrm{ldm}$ end a price for 1 ldm for groupage shipment from Italy will be offered which is 180, EUR

2/By applying the model for dynamic price the company has to consider the following price determinants:

$K_{1}$ - indicating irregularity of shipment $=1.1$

$K_{2}$-indicating special requirements for loading/unloading $=1.05$

$K_{3}$ - indicator for customer loyalty and regularity of orders $=1.05$

$\mathrm{K}_{4}$ - indicator for high season surcharge $=1.15$

Цената $\mathrm{P} 1=\mathrm{P} 0 * K 1 * K 2 * K 3 * K 4$

$\mathrm{P}_{0}=180$ EUR

By applying the model we get:

$\mathrm{P}_{1}=1.1 * 1.05 * 1.05 * 1.15 * 180 \quad \mathrm{P} 1=251, \mathrm{EUR}$

The dynamic price is just both for the transport company and the customer. The customer gets a decision for his irregular shipment for special loading requirement in the difficult situation before the shipper closes for summer holiday [4]. The company gets its surcharge of 71, EUR for finding capacity for the special shipment of the new customer in the high season. The dynamic price is $39 \%$ higher than the static one;

- taking loads by market price just to achieve better capacity at any price even under the cost.

Table 3 displays the revenues of import groupage truck on destination Germany - Bulgaria for the period January June 2020. Column two shows the formula how revenues are calculated considering the respective market price for each month(the price tendency was shown in table: 2, fig: 1)It is considered that the first $7 \mathrm{ldm}$ from the truck are reserved for regular customers with agreed, unchangeable prices. The rest $6.6 \mathrm{~m}$ from the truck (the truck is $13.6 \mathrm{~m}$ ) are loaded with casual shipments on market prices or the static tariff price if market price is higher; if lower the capacity remains empty.

The additional revenues by applying principles of dynamic pricing for e single truck per month for the period Jan June are 3016, EUR, which is $21 \%$ for the period. Normally companies do at least one journey per week and four per month and the additional revenues become 12064 EUR. The percent of additional revenues vary in extremely wide range per according to the market situation in the studied months from $0 \%$ in January to $81 \%$ in June. Its value depends on the market price and on part of load that is taken on free market not reserved by regular customers on fixed prices.

Table 3: Company revenues import groupage truck Germany - Bulgaria Jan -June 2020 in EUR

\begin{tabular}{|c|c|c|c|c|}
\hline Month & $\begin{array}{r}\text { Formula for } \\
\text { groupage truck capacity }\end{array}$ & $\begin{array}{r}\text { Revenue by } \\
\text { dynamic pricing }\end{array}$ & $\begin{array}{r}\text { Revenues } \\
\text { by static tariff }\end{array}$ & $\begin{array}{c}\text { Difference } \\
\text { in revenues }\end{array}$ \\
\hline Jan & $13,6 * 178$ & 2420 & 2420 & 0 \\
\hline Feb & $7 * 178+6,6 * 184$ & 2460 & 2420 & 39.6 \\
\hline March & $13,6 * 178+6,6 * 194$ & 2526 & 2420 & 105.4 \\
\hline April & $7 * 178+6 * 138$ & 2156.8 & 1246 & 910.8 \\
\hline May & $7 * 178+6,6 * 143$ & 2189.8 & 1246 & 1016.4 \\
\hline June & $7 * 178+6,6 * 154$ & 2262.4 & 10998 & 3016 \\
\hline Total & & 14015 & & 943.8 \\
\hline revenues & & & & 1246 \\
\hline
\end{tabular}

Source: Real company data, calculations by author 


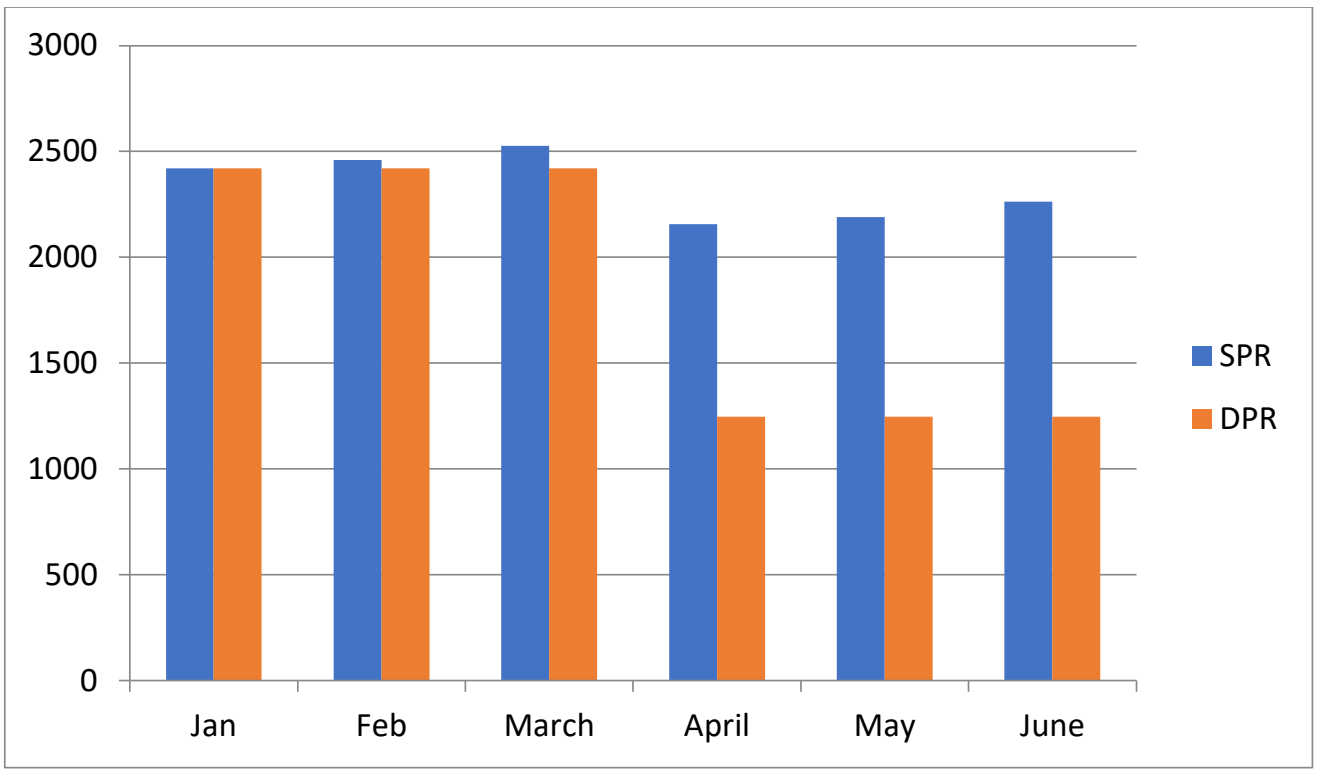

Fig: 2 Comparison of revenues from an import groupage truck Germany/Bulgaria by dynamic and static pricing

Sources: calculation by author from real company data

DPR - revenues by dynamic pricing

SPR - revenues by static prices

\section{CONCLUSION}

Analyzing dynamic pricing approaches we can make the following conclusions:

> Applying dynamic pricing strategies by highly changeable and unprodictable market situation is crucial for survival of trucking companies and keeping their profitability as there are no additional cost for its implementation;

$>$ The percentage of regular customers with regular orders on fixed prices is the basis of stable development in turbulent market conditions and crises;

$>$ The revenues realized on the basis of dynamic price model very in narrower range $10-15 \%$ whereas the ones for maximizing capacity on market prices vary widely from $0-81 \%$. The ultimate values of course are reached in extra-ordinary situations as pandemic crisis. The first approach is rather an way for maximizing revenues while the other one tends to minimize losses.

$>$ Combining skillfully both methods a company can improve its revenues by $20 \%$ on average.

\section{REFERENCES}

[1] Arthur Sesyl Pygu, "The Economics of Welfare "(1920).

[2] Thomas T. Nagle/Reed K. Holden, The strategy and Tactics of Pricig, 211-233, 1995

[3] J. Stoichev, Pricing politic, NBU, Sofia 2002

[4] Sarah Maxwell, The price is wrong, 163-187, 2002

[5] Ralph Cassady, Techniques and Purposes of Price Discrimination, Journal of Marketing, 11, 146, 1946

[6] H. Nikolova, Itnernational Transport and Spedition, Unwe, Sofia, 2011

[7] Ball, Donald and McCulloch, Wendell-Jr., International Bussiness: The Challenge of Global Competition, Irwin/McGraw -Hill, sixth edition, 1996

[8] Schumpeter, Flexible Figures, Jan 28, 2016, https://www.economist.com/business/2016/01/28/flexible-figures

[9]Scientific Journal Concept, issue 14 - ART 14686, :http://e-koncept.ru/2014/14686

[10]https://spravochnick.ru/cenoobrazovanie_i_ocenka_biznesa/cenoobrazovanie/dinamicheskoe_cenoobrazovanie/, $\underline{2018}$ 
[11] whttps://vc.ru/flood/45560-dinamicheskoe-cenoobrazovanie, Sep 12, 2018

[12] Land Transport Solutions during COVID-19, Customer information COVID-19 | Measures to protect employees and Supply Chains, https://www.yusen-logistics.com/en/land-transport-tailored-solutions-covid-19, March $9^{\text {th }} 2020$

[13] Transport and Covid-19: Responses and Resources, https://www.itf-oecd.org/covid-19, March 26, 2020

[14] COVID-19: how some countries around the world are supporting road transport https://www.iru.org/resources/newsroom/covid-19-how-some-countries-around-world-are-supporting-road-transport, April 9, 2020

[15] https://www.nsi.bg/bg/content/7508/ by month, 2020

[16] Kuehne+Nagel AG, Annual report 2020, https://home.kuehne-nagel.com/, December 2020 